\title{
LUNTURNYA PERMAINAN TRADISIONAL
}

\author{
M. Husein. MR \\ Program Studi Sosiologi, Universitas Malikussaleh Lhokseumawe \\ Aceh-Indonesia
}

Korespondensi: mhusen@unimal.ac.id

\begin{abstract}
Abstrak: Zaman sekarang ini, semakin maju terknologi akan merubah secara perlahan pola pikir dan kehidupan sosial suatu masyarakat. Salah satunya permainan tradisional yang sudah perlahan luntur dan tergeser dengan adanya permainan modern. Dewasa sekarang ini, anak-anak lebih menyukai atau mengemari permainan modern dibanding dengan permainan tradisional. Seiring dengan kemajuan ilmu pengetahuan dan teknologi, bermain tidak lagi menjadi aktivitas fisik dalam daya tumbuh kembang seorang anak. Dalam penelitiannya ini menggunakan metode kualitatif deskriptif, menganalisis tentang fakta sosial. Sehingga dapat disimpulkan bahwa ada tiga hal, yang pertama adanya pergeseran budaya dan nilai terhadap suatu permainan, kedua, kurangnya ketertarikan permainan tradisional karena tidak adanya tantangan dalam suatu permainan dan ketiga, pengaruh lingkungan dan pola interaksi yang menyebabkan tingkatnya kontak langsung dengan anak-anak yang bermain permainan modern.
\end{abstract}

Kata Kunci: Pergeseran Budaya, Perubahan Nilai, Eksistensi, Pola Interaksi. 


\section{A. Pendahuluan}

Tidak dapat diketepikan bahwasanya kemajuan zaman saat ini makin mendorong kemajuan teknologi dalam bidang apapun. Teknologi yang diciptakan tentu dari satu sisi, mampu membantu memudahkan pekerjaan manusia itu sendiri. Disisi lain pula, terdapat efek yang menyebabkan terjadinya disfungsi dalam teknologi itu sendiri. Begitu juga dengan kehidupan sosial suatu masyarakat, akan mengalami perubahan. Perubahan tersebut bisa saja terjadi dalam tenggang waktu yang lamban, begitu juga sebaliknya akan mengalami perubahan secara cepat. Sebagai salah satu contoh pada permainan tradisional anak-anak dewasa ini yang mulai meluntur dan tergeserkan dengan adanya permainan modern, yang kian digemari oleh anak-anak saat sekarang, ketimbang jenis-jenis permaianan tradisional.

Pada intinya, permainan dan bermain merupakan bagian dari dunia anakanak, melalui bermain permainan anak-anak dapat memperoleh kesenangan tersendiri bagi mereka. Bermain permainan merupakan salah satu jenis aktivitas fisik yang dapat membantu tumbuh kembang anak. Namun, seiring dengan kemajuan ilmu pengetahuan dan teknologi (IPTEK), bermain tidak lagi menjadi aktivitas fisik yang mendukung tumbuh kembang anak. Permainan yang dimainkan adalah jenis permainan seperti game Dawai atau Game Online

Subrahmayan (Ukasyah dan Irfansyah, 2015) menyatakan anak cenderung tidak bergerak ketika memainkan permainan yang sudah memanfaatkan teknologi. Anak hanya duduk di depan televisi dan bermain dengan menggunakan media tanpa banyak bergerak. Hal ini pada akhirnya mengakibatkan anak memiliki kecenderungan untuk mengalami obesitas. Tidak hanya berdampak pada pertumbuhan dan perkembangan fisik anak tetapi juga berdampak pada perkembangan sosial, emosional dan mental anak.

Pada dasarnya anak-anak membutuhkan aktivitas fisik yang memadai untuk merangsang pertumbuhan dan perkembangan anak. Aktivitas fisik yang dilakukan juga akan bermanfaat bagi kesehatan dan kebugaran tubuh anak. Salah satu aktivitas fisik yang sering dilakukan anak-anak adalah bermain suatu permainan. Dengan bermain banyak manfaat yang dapat diperoleh anak 
misalnya,anak menjadi senang, dapat menjalin persahabatan, memperkaya gerak yang dimiliki anak dan dapat belajar keterampilan baru.

Permainan tradisional merupakan salah satu sarana bermain bagi anak. Selain bermanfaat bagi kesehatan, kebugaran dan tumbuh kembang anak, terdapat juga nilai-nilai positif yang terkandung dalam permainan tradisional misalnya kejujuran, kerjasama, sportif, tolong menolong, tanggung jawab, disiplin dan masih banyak lagi dimana hal-hal tersebut dapat membangun karakter anak. Selain itu, Permainan tradisional lebih efektif dari kegiatan sehari-hari dalam rangka untuk mengembangkan kontrol objek, kemampuan lokomotor dan keterampilan dasar. Hakimeh Albari dkk, 2009.

Sebagian besar permainan tradisional dan olahraga merupakan ekspresi budaya asli dan cara hidup yang memberikan kontribusi terhadap identitas umum kemanusiaan telah menghilang dan yang masih bertahan juga terancam hilang atau punah karena pengaruh globalisasi dan harmonisasi keragaman warisan olahraga dunia (Jogen Boro dkk, 2015: 88).

Selain itu, permainan tradisional juga dapat melatih kemampuan sosial para pemainnya. Inilah yang membedakan permainan tradisional dengan permainan modern seperti game Dawai (Gadget). Pada umumnya, mainan tradisional adalah permainan yang membutuhkan lebih dari satu pemain, Hal ini sangat berbeda dengan bentuk permainan modern. Kemampuan sosial anak tidak terlalu dipentingkan dalam permainan modern ini, malah cenderung diabaikan karena pada umumnya mainan modern berbentuk permainan individual di mana anak dapat bermain sendiri tanpa kehadiran teman-temannya. Sekalipun dimainkan oleh beberapa anak, kemampuan interaksi anak dengan temannya tidak terlalu terlihat. Pada dasarnya sang anak terfokus pada permainan yang ada di hadapannya. Mainan modern cenderung bersifat agresif, sehingga tidak mustahil anak bersifat agresif karena pengaruh dari mainan ini (Gustiana. 2018: 55). sebagaimana kita pahami, bahawa teknologi juga dapat mengubah kebudayaan dengan cepat. Misalnya, pada umumnya manusia itu harus saling berinteraksi dan saling membutuhkan satu dengan lainnya. Namun, teknologi mampu mengubahnya dengan cepat. Dengan teknologi, generasi millenial cendreng terhadap individualis yang mengejar pola gaya hidup yang eksis di sosial media. 
Kehadiran teknologi membuat generasi dimasa kini, mulai meninggalkan nilai-nilai budaya yang telah diwariskan oleh generasi sebelumnya, dengan adanya teknologi, nilai-nilai yang ditanam pada diri seorang anak akan ikut hilang mengikuti arus dan perkembangan zaman. Hal ini dapat kita lihat disektor pedesaan, yang mana masyarakat di sektor ini sangat ketara dengan nilai-nilai budaya, baik dari segi kehidupan sosial dam keseharian mareka, juga dari segi aspek budaya dan agama, begitu juga dengan anak-anak yang selalu bermain dengan perbmainan tradisional dengan menggunakan bahan-bahan disekitarnya sebagai media permainnannya. Manakala, dimasa sekarang, bahkan ada diantara generasi muda yang tidak kengenal dengan tarian tradisional, alat musik tradisional. Begitujuga dengan permain tradisional yang telah di wariskan dari generasi sebelumnya kepada generasi selanjutnya, talahpun mulai luntur. Yang mana anak-anak yang dulunya di kota sama ada dipedesaan khususnya sangat melekat dengan permainan-permainan tradisional.

Perkembangan teknologi memang mempengaruhi lunturnya permainan tradisional dalam kehidupan anak-anak, apalagi dengan adanya game Dawai (Gedge)t, dan juga setelah ada beberapa masyarakat membuka usaha warnet, anak-anak semakin meningalkan permainan tradisional, dan semua pengunjung warnet tersebut di dominasi anak-anak untuk main game Dawai apalagi pada waktu malam hari setelah magrib semua dipenuhi anak-anak yang masih duduk dibangku dasar (SD) dan itu sangat berpengaruh untuk disalah gunakan dengan melihat situs yang kurang mendidik kalau tanpa ada pengawasan orang tua. Banyak anak-anak sekarang tidak lagi mengenal nama-nama permainan tradisional apalagi untuk memainkannya, malahan anak-anak sekarang lebih tahu nama-nama game yang ada di Dawai (gadget)nya dan lebih tahu cara dan sistem mainnya dari pada permainan tradisional.

Sebenarnya permainan tradisional merupakan permainan yang relatif sederhana namun memberikan manfaat luar biasa jika kita menelusuri makna dari permainan itu secara mendalam, kondisi lingkungan bermain bagi anak yang sudah berbeda, menjadiakan permainan tradisional jarang di mainkan oleh anakanak. Padahal permainan tradisional sangat gampang untuk dimainkan dan seru apa lagi kalau rame-rame dan alat yang dimainkanpun tergolong sederhana dan 
gampang di cari, bahkan tidak mengeluarkan biaya sama sekali. Dan manfaat dari permainan tradisionalpun juga baik untuk kecerdasan dan skil pada anak-anak.

Pemainan tradisional dewasa ini sudah jarang kita lihat seperti, bermain lompat karet, permainan angklek, main keong,main layang-layang, main congklak, main gasing, main patok lele, dan lain sebagainya.Kebanyakan permainan yang di mainnkan oleh anak-anak di desa, selepas pulang sekolah, kebanyakan dari para anak-anak justru menghabiskan waktunya untuk main game dirumahnya, maupun di warnet. Hal ini sangat berbeda dengan apa yang dilakukan oleh anak-anak zaman dahulu sebelum berkembangnya teknologi masuk ke Desa mereka. Dulu anak-anak selepas pulang sekolah bermain sama teman-temannya dengan peralatan seadanya, dan berbagai permainan tradisional lainnya yang mareka mainkan.

\section{B. Metode Penelitian}

Dalam penelitian ini, peneliti menggunakan metode kualitatif deskripstif dengan menganalisis fakta sosial terhadap eksistensi permainan modern dan melunturnya permainan tradisional.

\section{Pembahasan}

Menurut koentjaningrat perubahan budaya adalah pergeseran, pengurangan, penembahan, dan perkembangan unsur-unsur dalam suatu kebudayaan. Secara sederhana, perubahan budaya merupakan dinamika yang terjadi akibat benturan-benturan antar unsur budaya yang berbeda-beda (Elly, 2011: 42).

Ada lima faktor yang menjadi penyebab perubahan kebudayan yaitu:

1. Perubahan lingkungan alam.

2. Perubahan yang di sebabkan adanya kontak dengan suatu kelompok lain.

3. Perubahan karena adanya penemuan.

4. Perubahan yang terjadi karena suatu masyarakat atau bangsa mengadopsi beberapa elemen kebudayaan material yang telah di kembangkan oleh bangsa lain di tempat lain. 
5. Perubahan yang terjadi karena suatu bangsa memodifikasi cara hidupnya dengan mengadopsi suatu pengetahuan atau kepercayaan baru, atau kerena perubahan dalam pandangan hidup dan konsepsinya tentang realitas (Elly, 2011: 44).

Kebudayaan yang di kemukakan oleh Koentjaraningrat yang mengemukakan bahwa kebudayaan adalah keseluruhan sistem gagasan, tindakan dan hasil karya manusia dalam rangka kehidupan masyarakat yang di jadikan milik diri manusia dengan belajar. Dan perubahan kebudayaan bisa terjadi dikarnakan adanya pergeseran, pengurangan, penembahan, dan perkembangan unsur-unsur dalam suatu kebudayaan.

Jadi yang menjadi kaitannya lunturnya permainan tradisional, yang terjadi di kalangan anak-anak didesa disebabkan perubahan lingkungan alam dimana sekarang anak-anak sudah tidak lagi pempunyai tempat untuk bermaian karna sudah padat dengan pemukiman penduduk, dan juga munculnya penemuanpenemuan baru seperti teknologi yang kemudian diadopsi oleh masyarakat kita sebagai sebuah kebutuhan atau untuk hiburan semata.juga bisa saja disebabkan leh kurangnya perhatian masyarakat secara umumnya dan keluarga dalam memperkenalkan dan mensosialisasi permainan tradisional tersebut.

Menurut Koentjaraningrat (dalam Warsito 2012), Nilai budaya merupakan nilai yang terdiri atas konsepsi-konsepsi yang hidup dalam alam fikiran sebahagian besar warga masyarakat dalam hal-hal yang mereka anggap amat mulia. Sistem nilai yang ada dalam suatu masyarakat menjadi orientasi dan rujukan dalam bertindak bagi mereka. Oleh sebab itu, nilai budaya yang dimiliki seseorang mempengaruhinya dalam mengambil alternatif, cara-cara, alat-alat dan tujuan-tujuan pembuatan yang tersedia.

\section{Lunturnya permainan tradisional}

a. Luntur

Luntur yang dimaksud disini ialah, mengandung makna bahwa budaya permainan tradisional pada anak-anak mulai hilang secara perlahan-lahan sesuai dengan perkembangan zaman yang semakain canggih lebih banyak memanfaatkan teknologi dari pada peralatan-peralatan yang sederhana dan tradisional. 
Dalam kamus besar indonesia (KBBI) kata luntur memiliki banyak arti seperti lintur untuk mengartiakan warna pakaian, kepercayaan, popularitas, misalnya kepercayaan masyarakat inonesia terhadap wakil rakyat yang sudah luntur (hilangnya popularitas/pamor wakil rakyat). Dalam judul penelitian ini kata luntur di artikan sebagai hilangnya suatu budaya yang mengalami proses perlahan-lahan sehingga dengan berjalannya waktu budaya, nilai-nilai dan norma yang ada dalam kehidupan masyarakat tersebut akan mengalami luntur atau hilang secara perlahan.

b. Permainan tradisional

Permainan tradisional adalah permainan yang sudah ada sejak zaman dahulu, dimainkan dari generasi ke generasi. Alat bantu dalam permainan tradisional terbuat dari kayu, bambu, batok, dan benda-benda sekitar. Artinya, permainan tradisional tidak membutuhkan biaya besar.

Adapun alat bantu dalam permainan modern adalah kertas, besi, atau benda lain. Permainan modern mulai ditemukan setelah abad ke-20. Sekarang ini, permainan anak semakin berkembang sesuai tuntutan zaman. Anak-anak bermain menggunakan alat berteknologi, misalnya telepon genggam, gawai (gadget), komputer, dan laptop. (Riski Yulita, 2017: 1).

c. Nilai Permainan Tradisional

Salah satu perubahan yang terjadi di masyarakat Indonesia saat ini terkait dengan permainan tradisional. Kehadiran berbagai bentuk mainan dan juga berbagai jenis permainan seperti game telah menyebabkan eksistensi permainan tradisional dari kehidupan anak-anak tergantikan dengan adanya game juga mainan-mainan lainnya. pertumbuhan permainan game berjalan seiring dengan pertumbuhan gadget di Indonesia dewasa ini semakin pesat. Maka tidak meherankan anak-anak kini beralih untuk bermain game.

Para ahli-ahli ilmu sosial berpendapat bahawa masyarakat merupakan manusia yang selalu dinamis. Setiap masyarakat akan selalu mengalami perubahan. Perubahan ada yang tampak jelas dan ada pula yang samar, ada yang berlangsung lambat dan ada yang berlangsung cepat, ada yang mengalami perubahan sebagian dan ada juga yang mengalami perubahan menyeluruh. Perubahan itu ada yang ke arah maju ada yang mundur (Syarbaini, dkk. 2004). 
Menurut Yulianto (2011) Permainan tradisional memiliki banyak manfaat yang baik untuk perkembangan anak karena fisik dan emosi anak terlibat langsung sehingga dapat mempengaruhi pertumbuhannya. Dan apabila permainan modern dikombinasikan dengan permainan tradisional maka akan memberikan manfaat yang saling melengkapi bagi perkembangan anak, karena dalam permainan modern anak mendapat manfaat yang bersifat fisik, psikologis, dan aspek sosial. Adapun manfaat dari permainan tradisonal yang dapat mempengaruhi perkembangan anak adalah mengembangkan kecerdasan intelektual pada anak, mengembangkan kecerdasan emosi pada anak, mengembangkan daya kreatifitas pada anak, meningkatkan kemampun bersosialisasi, dan melatih kemampuan motorik

d. Ketertarikan dan Impak permainan modern

Bila dibandingkan dengan permainan tradisional, para generasis sekarang lebih memilih untuk bermain dengan berbagai permainan game online, dan berbaigai permainan lainnya dibandingkan dengan permainan tradisional.hal ini di sebab game online banyak jenis permainannya, lebih menghibur dibandingkan permainan tradisional sehingga anak-anak bisa memainkan game yang disukainya, seperti PUBG yang permainannya yaitu berperang. Anak-anak menyukai game ini karena keseruannya yang banyak tantangan. Aplikasi permainan game online dimana wilayah permainan yang luas dengan gambar yang nampak nyata. Game online seperti PUBG dapat bermain bersama dalam satu tim dan bisa saling berkomunikasi.

Keseruan game online juga dapat dimainkan secara global dimana mereka harus saling mengalahkan satu sama lain. Game ini juga bisa dimainkan dengan orang lain diluar negeri, seperti orang Malaysia yang tergabung dalam game tersebut. Dalam permainan game online juga memiliki lokasi permainan yang berbeda-beda sehingga menambah tantangan, dan kemampuan pemainnya dapat ditingkatkan hingga menjadi kuat. Kemudian, anak-anak juga dapat mengikuti event pertandingan dalam game yang dapat memberikan tantangan baru dan juga hadiah jika memenangkannya. Hal ini sangat menghiburkan bermain game online, setentunya hal ini sanga bebeda sekali dengan permainan tradisional, yang permainannya tetap sama dan dan tidak ada perubahan, bahkan tidak ada 
tantangan sehingga membuat anak-anak menjadi bosan bermain permainan tradisional, seiring dengan perkembangan jaman dan kemajuan tehnologi, permainan tradisional mulai ditinggalkan oleh anak-anak dewasa ini. Hal ini, juga diikuti oleh aspek-aspek lainnya dalam interaksi mareka sehari-hari pada saat mareka bermain bersama. Yang mana diantara satu individu dengan individu lainnya, juga dalam satu kelompok mereka saling mempengaruhi, sehingga mereka mencoba untuk bermain permainan yang baru.

Pengaruh teman pergaulan dimana anak-anak terdorong bermain game modern, mungkin saja mereka mulai bosan ataupun ingin mencoba permainan baru, yang lebih seru dan asyik menurut meraka. Dilain ini pula, setentunya ada di antara teman-teman sepermainnan meraka sudah memainkan game, atau permainan lainnya yang sangat menarik menurut mereka, dengan melihat permainan temannya yang menghiburkan membuat anak lainnya menyukainya dan ingin bermain game tersebut. Apalagi permainan ini, game modern dapat menambah pertemanan diantara anak-anak. Anak-anak yang bermain game memiliki teman dan memperkuat pertemanan dengan bisa bermain bersama temannya. Tetapi jika anak tidak bermain game online maka tidak ada teman. Sedangkan permainan tradisional tidak dimainkan lagi sebab tidak hanya membosankan, melainkan pengaruh teman pergaulan yang tidak lagi bermain game tersebut sehingga anak juga tidak ada teman untuk diajak bermain. Bahkan pengaruh orangtua yang melarang anak bermain tradisional yang membuat anak kotor mendorong anak tidak lagi bermain permainan tradisional.

Menurut koentjaningrat (1980) kebudayaan adalah keseluruhan perilaku dari manusia dan hasil yang di peroleh dari proses belajar dan segalanya tersusun dalam kehidupan masyarakat. Koentjaraningrat mengemukakan bahwa kebudayaan itu dibagi atau di golongkan dalam tiga wujud yaitu (a) wujud sebagai suatu kompleks dari ide-ide, gagasan, nilai-nilai, norma-normadan peraturan, (b) wujud kebudayaan sebagai suatu konpleks aktivitas serta tindakan berpola dari manusia dalam masyarakat, (c) wujud kebudayaan sebagai benda-benda hasil karya manusia.

Berdasarkan penjelasan koentjaningrat bahwa permainan (game) merupakan unsur dari kebudayaan yang wujudnya berasal dari karya manusia. 
Permainan yang berasal dari pemikiran manusia dalam prosesnya melalui pembelajaran. Manusia yang menyukai permainan tersebut akan belajar agar bisa memainkan permainan tersebut yang memainkan permainan tradisional hingga modern dimulai dari proses belajar hingga menimbulkan minat untuk memenangkan permainan tersebut.

Permainan tradisional seperti permainan layangan, permainan petak umpet, keong, karet merupakan bagian dari kebudayaan dimana permainan tersebut hasil karya manusia yang diwariskan dari generasi ke generasi.Tetapi perkembangan zaman membuat permainan pada anak mengalami perubahan.Perubahan tersebut diantaranya bahwa anak tidak lagi bermain permainan tradisional, melainkan memainkn permainan lebih modern, seperti game online.Salah satu penyebab terjadinya perubahan permainan pada anak di di gampong dengan hadirnya permainan modern seperti Gawai (Gadget) seperti handphone android dan penemuan internet hingga perancang game modern yang lebih menarik telah disebarkan ke seluruh masyarakat

Perubahan pada permainan tradisional ke permainan modern seperti game online di dikarenakan adanya kontak dengan suatu kelompok lain. Kontak ini mulai pada anak di Gampong tersebut yang memiliki kontak terutama tatap langsung dengan anak lainnya yang memiliki Gawai dan memainkan permainan modern. Kontak tersebut dilakukan melalui teman pergaulan. Begitu juga temannya yang sudah mengenal permainan modern juga adanya kontak dengan masyarakat lainnya diluar desa tersebut.Permainan modern tersebut dipelajarinya hingga mampu menguasainya dan dimainkannya. Permainan ini dipertahankan hingga sekarang karena permainan modern lebih menghiburkan bagi anak-anak dan tidak merasa bosan ketika memainkannya.

Meningkatkan pola interaksi anak dimana anak sering bermain game bersama temannya dan saling berinteraksi satu sama lain, terutama ketika bermain game online secara kelompok. Dengan adanya permainan modern ini yaitu game online dapat menambah pertemanan anak dimana anak tidak hanya berkawan sesama anak seGampong, juga berteman sama anak luar gampong yang dikenalinya ketika bermain game di pondok maupun warung kopi yang ada jaringan wifi. Kemudian, orangtua dapat mengontrol keberadaan anaknya, 
terutama keberadaan anaknya ketika tidak ada dirumah, seperti sering berada dipondok yang ada jaringan wifi dan bermain game. Jadi orangtua ketika mencari anak langsung mendatangi tempat tersebut. Anak juga tidak bermain jauh dari rumahnya, sebab ada membutuhkan jaringan wifi untuk bermain game, dan digampong sudah tersedia wifi yang ada dipondok. Bahkan orangtua juga sudah mengenal teman pergaulan anaknya dengan sering melihat ketika duduk bersama anaknya. Jika anaknya memiliki teman pergaulan tidak baik, maka orangtua bisa mencegahnya.

Seiring dengan perkembangan jaman dan kemajuan tehnologi, hal-hal yang dianggap mengandungi tradisional ataupun lebih dikenal dengan istilah-istilah “jadul atau enggak jaman” oleh generasi sekarang, mulai di tinggalkan. Begitu juga halnya dalam permaina anak-anak. Dengan adanya permainan-permainan modern, dikalangan anak-anakpun telah meninggalkan permainan-permainan tradisional yang merupakan warisan dari generasi sebelumnya. Adanya permainan modern yang bersifatnya lebih kepada individualis, telahpun menyebabkan berkurangnya waktu bermain dan berinteraksi antar sesame anak-anak lainnya.yang justru anak-anak menjadi individual yang menjalani kehidupan mereka lebih kepada individualistis. Hal ini, sangat jauh berbeda dengan permainan tradisional, yang justru menawarkan suatu nilai yang amat positif bagi perkembangan anak. Selain itu, permainan tradisional juga salah satu warisan budaya karena didalamnya juga terdapat lagu lagu daerah yang harusnya terus dilestarikan dan dipelihara eksistensinya. Permainan tradisional dianggap istimewa karena ada hal-hal yang membedakannya dengan permainan modern yang sedang berkembangan saat ini. Jika kita mampu lebih menelaah permainan tradisional, maka akan kita jumpai nilai-nilai permainan yang sangat menarik dan tentunya sangat baik untuk perkembangan karakter anak. Bahwa sebenarnya sebuah permainan yang baik untuk pembentukan karakter anak adalah mempunyai sisi yang berimbang.

Permainan modern seperti game online atau play station dianggap jauh lebih menarik, praktis, dan pastinya modern. Hal ini menimbulkan beberapa pengaruh pada perkembangan karakter anak. Jika kita lihat, permainan tradisional cenderung mendorong anak agar bergerak dan beraktivitas, sehingga mereka akan 
jauh lebih sehat, selain itu permainan tradisional yang rata-rata dilakukan bersama-sama, mendorong anak-anak untuk belajar bekerja sama dan saling menghargai. Sedangkan permainan modern bisa dilakukan seorang diri, duduk tenang, dan sambil bersantai. Sehingga badan yang seahat, kemampuan beradaptasi dan belajar bekerja sama sangat sulit didapatkan dari permainan modern. Selain ada juga factor lain mengapa anak tidak mengenal permainan tradisional, karena tidak ada peranan dari orang tua untuk memberikan pengetahuan kepada anak-anak mereka baik dalam institusi keluarga maupun dalam dalam sosial lingkungan masyarakat umum.

Permainan tradisional memiliki nilai-nilai positif yang dapat ditanamkan pada anak sejak dini melalui permainan yang mareka mainkan, misalnya seperti bermain galah, disini secara tidak langsung telah mengajari dan memupuk anakanak tersebut untuk bertanggung jawab, baik secara pribadi maupun tanggung jawab tim atau kelompoknya dalam permainan galah tersebut. Nilai-nilai tersebut, setentunya semuanya merupakan nilai-nilai yang sangat baik dan berguna dalam kehidupan anak. Permainan tradisional juga dapat membantu anak dalam menjalin hubungan sosial sehingga anak dapat bersosialisasi dengan lingkungan keluarga, sekolah, dan bahkan masyarakat luas. Sementara permainan modern yang justru membawa anak-anak kepada kehidupan yang bertolak belakang dengan niulainilai adat sosial budaya sebagai masyarakat yang beradab dab budipekerti yang luhur. Secara jujur, kehadiran permainan-permanina modern dewasa ini telah melunturkan permainan tradisional, juga yang sangat memprihatinkan telah terjejas kepada mentalitas, karakter dan berbagai masalah yang timbul kepada anaka-anak kita dewasa ini, masalah kesehatan anak dan berbagai masalah lainnya baik secara fisik maupun non fisik yang merupakan impak dari permainan modern yang ditimbulkan, selain dari lunturnya permainan tradisional, yang biasanya dimainkan oleh anak-anak di desa.

\section{Kesimpulan}

Memilih permainan modern yaitu game dawai lebih menghiburkan, sebab game online banyak jenis permainannya, memiliki banyak tantangan, tampilan aplikasi game nampak nyata, bisa bermain bersama teman secara online, dan 
mengikuti event pertandingan dan mendapatkan hadiah jika memenangkannya, pengaruh teman pergaulan dimana anak-anak terdorong bermain game modern karena banyak temannya sudah memainkan game tersebut, dan melihat permainan temannya yang menghiburkan membuat anak lainnya menyukainya dan ingin bermain game, dan jika anak tidak bermain game online maka tidak ada teman bermain. meningkatkan pola interaksi anak ketika bermain game online secara kelompok dan menambah pertemanan anak.di sisilain dengan adanya permainan geme online ini, berdampak yang sanagat signifikan dapat mempengaruhi mentalitas anak, juga dari segi aspek kesehatan yang lainnya, seperti berpangaruh terhadap kesehatan mata, mental dan lain-lain.

Maka disini di tuntun adanya peran orang tua juga masyarakat lingkungan sekitar sangat penting dalam mengembangkan budaya tradisional pada anak-anak saat ini, agar mereka tidak hanya bermain terus menerus dengan gadget, padahal permainan tradisional lebih seru jika dibandingkan dengan gadget. Tidak hanya itu saja, permainan tradisional juga bisa mengasah otak anak agar lebih berkembang dan kreatif untuk melakukan berbagai kegiatan yang berdampak bagi diri mereka sendiri. Mereka juga bisa lebih aktif dalam berbagai kegiatan. Jika dibandingkan dengan teknologi atau permainan modern, itu sangat jauh sekali karena gadget terlalu menguasai pola pikir anak, sehingga dapat membuat anak malas untuk belajar, mereka juga akan lebih mementingkan diri sendiri,

Dampak yang sangat signifikan, mereka tidak peduli dengan keadaan sekitar diera digital saat ini sudah banyak kita jumpai anak-anak dipedesaan yang sudah memiliki gadget diusia yang sangat dini, mereka lebih mengenal gadget dibandingkan permainan tradisional yang ditinganggal oleh generasi sebelumnya, yang merupakan warisan budaya dari leluhur yang diwariskan dari generasi kegenerasi selanjutnya. Tidak lah kita merasa heran, bahkan gadget sudah menjadi dunianya, bahkan mereka tidak bisa melakukan kegiatan tanpa gadget.

Lunturnya budaya tradisional juga dikarenakan perkembangan teknologi yang semakin canggih, permainan modern juga lebih menarik dan lebih asik dikalangan mereka. Gadget saat ini lebih menarik perhatian anak generasi sekarang daripada permainan tradisional. 
Secara umumnya, budaya yang merupakan adat kebiasaan untuk mewakili sifat diri manusia seharusnya tidak dilupakan. Semakin langka permainan tradisional di era sekarang, semakin jelas bahwa anak-anak sebagai penerus generasai masa hadapan telah diatur hidupnya oleh teknologi.oleh karena itu, adaptasi untuk terus melestarikan budaya yang ada seharusnya diterapkan pada semua kalangan terutama anak yang menjadi generasi penerus bangsa. Menjadi tanggung jawab semua bpihak, baik institusi keluarga, masyarakat secara umumnya dan pemerintah.sangat kita sayangkan, dan patut dikhawatirkan Jika budaya seperti itu bisa direbut oleh kemajuan teknologi, maka generasi mendatang tidak akan lagi sama sekali mengenali warisan budaya leluhurnya. 


\section{Daftar Pustaka}

Anggita, Agustina Mega. Dkk. 2018. "Eksistensi Permainan Tradisional Sebagai Warisan Budaya Bangsa". Journal of Sport Science and Education (Jossea) volume: 3, no: 2 oktober 2018: 55-59)

Dewi salmaprawiradilaga. Dkk. 2013. Mozaik teknologi pendidikan e-learning. Jakarta kencana prenada media grup.

Hakimeh Akbar et al. Iranian. 2009. The Effect of Traditional Games in Fundamental Motor Skill Development in 7-9 Years Old Boys. Iran. Journal of Pediatrics Volume 19 No. 2, Juni 2009: 123-129.

Ilham 27 juni 2017 Gadget makanan apa itu di akses agustus 2020 dari: www.kompssiana.com/osakurniawanhilham/gedgetmakananapaitu_5500ed $3 e 813112020$

Jogen Boro et al. IOSR. 2015. Journal of Humanities and Social Science (IOSR JHSS) Volume 20 Issue 3 Ver. V1, March 2015: 87-91Moller, Stephanie, Arthur S. Alderson, and Francois Nielsen. 2009. "Changing Patterns of Income Inequality in U.S. Counties, 1970-2000." American Journal of Sociology 114(4):1037-1101.

Koentjaraningrat. 2003. Pengantar Antropilogi. Jakarta: Rineka Cipta.

Rizki Yulita. 2017. Permainan Tradisional Anak Nusantara. Jakarta Timur. Badan Pengembangan dan Pembinaan Bahasa Jalan Daksinapati Barat IV.

Setiadi Elly M. Dkk. 2011. Ilmu Sosial dan Budaya Dasar. Jakarta: Kencana.

Syarbaini, Syahril., Rahman, \& Monang Djihado. 2004. Sosiologi dan Politik. Bogor: Ghalia Indonesia.

Ukasyah Q.A.P dan Irfansyah.2015. "Identifikasi Faktor-Faktor Permainan Tradisional Bebentengan sebagai Basis Perancangan Game Pemicu Peningkatan Sistem Motorik Anak. Bandung". Jurnal Sosioteknologi, Volume 14 No. 2, Agustus 2015: $124: 140$. 